\title{
Respirando el verano, Fuente Colombiana de Cien años de soledad
}

El éxito descomunal de Cien años de soledad ha provocado una búsqueda afanosa de su genealogía. Marió Vargas Llosa ha identificado los antecedentes biográficos de su galería de personajes pintorescos ${ }^{1}$ en tanto que Mario Benedetti y otros ocho "asediantes" han comprobado que varios elementos de las obras anteriores de García Márquez se fueron fundiendo para lograr la máxima expresión de la obra maestra. ${ }^{2}$ Emir Rodríguez Monegal, entre otros, ha señalado la influencia de ciertas obras clásicas de la literatura universal como Pantagruel de Rabelais, Don Quixote y la novela de caballería y Orlando de Virginia Woolf. ${ }^{3}$ Hasta ha habido una acusación de plagio lanzada infelizmente por Miguel Angel Asturias respecto a La buisqueda del absoluto de Balzac. Precisamente dévido a este afán por descubrir los secretos de la gestación de Cien años de soledad, sorprende la casi nula investigación de sus raíces colombianas. ${ }^{4}$ Cinco años antes de la publicación de Cien años de soledad, Respirando el verano, primera novela del poeta-pintor Héctor Rojas Herazo

\footnotetext{
1 Mario Vargas Llosa, “García Márquez: de Aracataca a Macondo,', 9 asedios a Garcla Marquez, Santiago de Chile: Editorial Universitaria, 1969, pp. 126-146; también Historia de un deicidio, Barcelona: Barral Editores, 1971.

2" "Todos los libros anteriores, aún los más notables (como Los funerales de la Mamá Grande y El coronel no tiene quien le escriba) se convierten ahora en un intermitente borrador de esta novela excepcional, en la trama de datos más o menos verosímiles que servirán de trampolín para el gran salto imaginativo. Aparentemente cada uno de los libros anteriores fue un fragmento de la historia de Macondo (aún los relatos que no transcurren en ese pueblo, se refieren a él e integran su mundo) y éste de ahora es la historia total" (Mario Benedetti, "Gabriel Garcia Márquez o la vigilia dentro del sueno.' en 9 asedios a Garcia Márquez, pp. 18-19). Los otros asediantes son Emmanuel Carballo, Pedro Lastra, Juan Loveluck, Julio Ortega, José Miguel Oviedo, Angel Rama, Mario Vargas Llosa y Ernesto Volkening.

${ }^{3}$ Emir Rodríguez Monegal, "Novedad y anacronismo,", Narradores de esta América, II, Buenos Aires: Editorial Alfa Argentina, 1974, p. 286. El mismo Garcia Márquez confiesa en la propia novela la influencia de Rabelais cuando el personaje Gabriel sale para Europa "con dos mudas de ropa, un par de zapatos y las obras completas de Rabelais"' (Cien anos de soledad, 3a ed., Buenos Aires: Sudamericana, sept. 1967, p. 340). Las citas posteriores tambię́n provienen de esta edición.

${ }^{4}$ Que yo sepa, la única excepción es el excelente estudio de Lucila Inés Mena: "La Casa grande: el fracaso de un orden social," Hispamérica, I, 2 (Dic. 1972), pp. 3-17.
} 
(1922), mereció el segundo premio de novela en el concurso Esso. El estudio de los puntos de contacto entre estas dos novelas revelará la deuda que tiene García Márquez con su excolega del grupo de Barranquilla, ${ }^{5}$ sin que se rebaje el talento genial del creador de Macondo. Al contrario, el cotejo destacará la manera artística con que García Márquez adaptó y elaboró ciertos elementos de su compatriota, entretejiéndolos en una estructura novelística totalizante y confiriéndoles una verdadera trascendencia universal que no se encuentra en Respirando el verano.

Como Cien años de soledad, Respirando el verano es la crónica de una sola familia, que abarca poco menos de cien años, en un pueblo tropical de la costa norte de Colombia. En lo que más se parecen las dos novelas es en la caracterización de los personajes que integran las dos familias, en la visión mágicorrealista del mundo y en el estilo de ciertos pasajes, aunque hay que hacer constar que el estilo en general de las dos obras no es nada semejante. Por mucho que se parezcan los personajes macondinos a los de Rojas Herazo, no hay entre ellos una equivalencia total, o sea que a veces un personaje de Respirando el verano parece influir en más de uno de Cien años de soledad, y otras veces, son varios personajes de Rojas Herazo los que contribuyen a la creación de uno solo de los Buendía.

\section{CELIA--URSULA BUENDIA, EL CORONEL AURELIANO}

Anticipando a Ursula Buendía, Celia es el eje de su familia y sobrevive tanto a su marido como a algunos de sus hijos. Nacida en 1855, Celia todavía tiene bastante vigor a los ochenta y ocho años para anunciar el fin del verano, de la misma manera tajante que caracteriza las afirmaciones de los Buendia: “--Hoy en la madrugada va a llover, lo sé porque los huesos de la pierna han empezado a dolerme', (p. 207). ${ }^{6}$

Igual que Ursula, Celia se identifica totalmente con la casa. Con un toque mágicorrealista digno de García Márquez, la muerte de Celia parece precipitar el derrumbe de la casa:

A los tres días de muerta la casa se derrumbó de golpe como si alguien le hubiese dado un brusco manotazo. Ella la presentía y algunas veces, muy pocas, habló de eso con sus hijos. Sin embargo parecía no darle importancia a este aspecto, el más inquietante y misterioso de su existencia. . . Fue que ella y la casa se volvieron un solo organismo. (p. 123)

Un año antes, ella había previsto su propia muerte: “--El año entrante ni la casa ni yo estaremos en este lugar'” (p. 25). Uno de los recuerdos más persistentes de Celia es el del día en que dos de sus hijas trataron de persuadirla que abandonara la casa destartalada. En un gesto propio de Ursula, Celia "se encerró en un hosco mutismo"' (p. 132) y "se fue a lo profundo del patio, bajo el árbol de guayabo, y allí se quedó el resto de la tarde" ' (p. 24) hasta

5 “ 'Hacía la década de 1950 se formó a su (José Félix Fuenmayor) alrededor un grupo de artistas jóvenes que se conoció con el nombre de "La Cueva". A este grupo pertenecieron -entre otros--: Ramón Vinyes, Alejandro Obregón, Gabriel García Márquez, Alvaro Cepeda Samudio, Germán Vargas, Héctor Rojas Herazo y Alfonso Fuenmayor', (Lucila Inés Mena, "La casa grande, el fracaso de un orden social,'” op. cit., p. 17).

${ }^{6}$ Las citas provienen de la primera edición: Respirando el verano, Bogotá: Ediciones Tercer Mundo, dic. 1962. 
que las hijas desistieron. Cuando José Arcadio Buendía propone trasladar a Macondo a un lugar más propicio, Ursula se opone: "en una secreta e implacable labor de hormiguita predispuso a las mujeres de la aldea contra la veleidad de sus hombres"' (p. 19). Con estas palabras el conflicto personal entre José Arcadio Buendía y Ursula se transforma en el conflicto arquetípico entre el marido idealista o soñador y la mujer práctica. La crisis se resuelve en una de las inolvidables salidas breves y tajantes que salpican de vez en cuando el estilo de crónica del narrador omnisciente. Cuando José Arcadio Buendía afirma que sí pueden abandonar a Macondo porque todavía nadie ha muerto allí, Ursula le contesta "con una suave firmeza: --Si es necesario que yo me muera para que se queden aquí, me muero", (p. 19). Luego, después de dirigir la atención de su marido a sus dos hijos, Ursula "seguía barriendo la casa que ahora estaba segura de no abandonar en el resto de su vida" (p. 20).

Cuando Celia se enfrenta al peligro de perder la casa por una hipoteca: " "cogía entre sus manos-- con dura pasión, con hambre, casi con odio, un pequeño ícono de San Antonio tallado en una tagua y lo iba metiendo, por turno, en los escondrijos más inusitados de la casa" (p. 133). En Cien años de soledall la estatua de San José llena de dinero y las bolsas escondidas por Ursula llegan casi a constituir un motivo recurrente. Aparece por primera vez nacia la mitad de la novela cuando Aureliano Segundo empapela la casa con billetes de a peso (p. 168). Unas cuarenta páginas más adelante, Ursula, ya envejecida, " 'fastidiaba a los forasteros con la preguntadera de si nohabían dejado en la casa, por los tiempos de la guerra, un San José de yeso para que lo guardara mientras pasaba la lluvia" (p. 212). Durante el diluvio, Aureliano Segundo trata de recuperar su fortuna, excavando toda la casa buscando en vano las tres bolsas de monedas escondidas por Ursula (pp. 278-80). Una generación después, el escondite se revela milagrosamente, cuando el "papa" José Arcadio y uno de los cuatro niños enviciados ven "un resplandor amarillo a través del cemento cristalizado" (p. 314).

A unque en Respirando el verano no aparece más que una guerra civil, la de los Mil Días (1899-1902), Celia la sufre en carne viva. A su marido lo llevan preso " arrastrándole de la garganta con una cuerda"' (p. 158). Veintidós soldados se instalan en la casa sin permiso. Arrancan ladrillos para hacer fogones, mastican "en las alcobas, entre los caballos y los muebles hendidos a machete" (p. 158). Un cabo, indio serrano, le habla descaradamente a Julia, la hija mayor, y cuatro soldados le rompen el piano rellenándolo de comida. El hijo Jorge vuelve de la guerra con "el rostro amarillo y esquelético azuleado por la barba" (p. 158). Celia misma resulta herida en el brazo "por la bala que había rebotado en uno de los arcos del comedor"' (p. 158). De una manera semejante, Ursula aguanta los vaivenes de veinte años de guerras civiles, e incluso encuentros violentos con su propio nieto Arcadio y hasta con su hijo Aureliano cuando éstos se dejan embrutecer por la guerra. Los dos nietos, Arcadio y Aureliano José, mueren violentamente y el coronel Aureliano regresa de la primera guerra tan deshecho como el Jorge de Respirando el verano: "Parecía un pordiosero. Tenía la ropa desgarrada, el cabello y la barba enmarañados, y estaba descalzo" (p. 109).

Terminadas las guerras civiles, Ursula saca fuerzas de flaqueza y rejuvenece la casa.

“A hora van a ver quién soy yo," dijo cuando supo que su hijo viviría. "No habrá 
una casa mejor, ni más abierta a todo el mundo, que esta casa de locos." La hizo lavar y pintar, cambió los muebles, restauró el jardín y sembró flores nuevas, y abrió puertas y ventanas para que entrara hasta los dormitorios la deslumbrante claridad del verano. (p. 157).

Más de una generación después, pasadas las lluvias, Ursula reacciona contra la invasión de las cucarachas y de una manera febril vuelve a restaurar la casa por segunda vez:

"No es posible vivir en esta negligencia," decía. "A este paso terminaremos devorados por las bestias." Desde entonces no tuvo un instante de reposo. Levantada desde antes del amanecer, recurría a quien estuviera disponible, incuusive a los niños. Puso al sol las escasas ropas que todavía estaban en condiciones de ser usadas, ahuyentó las cucarachas con sorpresivos asaltos de insecticida, raspó las venas del comején en puertas y ventanas y asfixió con cal viva a las hormigas en sus madrigueras. La fiebre de restauración acabó por llevarla a los cuartos olvidados. . . (p. 284).

Lo que es una constante en Ursula tambiën se anticipa en Celia y con palabras parecidas, pero sólo una vez. A los setenta y seis años, Celia, acompañada de sus nietos, se había reanimado bañándose en el mar: "Aquella mañana parecía más vivaracha y minúscula. 'Como una hormiguita arriera,' pensó Anselmo'' (p.68).

Empequeñecida por la vejez y por la muerte, Celia es presentada con términos semejantes a los que había de emplear García Márquez para describir a la matriarca de los Buendía. Al morirse en 1948 a los noventa y tres años, Celia parece estar "durmiendo dentro de su ataúd como una de sus muñecas de maíz' (p. 135). En su noche final se ve "empequeñecida y seca como una fruta a la que se ha despojado de toda su pulpa"' (p. 135). El año anterior tenía "el aspecto de una muñeca siniestra, de un juguete al que se le estuviese finalizando la cuerda" (p. 25). De nuevo García Márquez supera a Rojas Herazo convirtiendo la imagen de la muñeca en toda una escena dramática. Durante el diluvio, A maranta Ursula y el pequeño Aureliano jugaban con su tatarabuela Ursula como si fuera un juguete: "La tuvieron por una gran muñeca decrépita que llevaban y traían por los rincones, disfrazada con trapos de colores y la cara pintada con hollín y achiote"' (p. 277). En los últimos meses de su vida, Ursula, igua! "u Culia, "era una ciruela pasa perdida dentro del camisón"' (p. 290). No cabe duda de que estas descripciones, por mucho que se parezcan, producen un efecto distinto en cada obra. Como el lector de Cien años de soledad ha convivido con Ursula durante varias horas de lectura, el presenciar su transformación de la mujer más enérgica de Macondo a una muñeca de trapo ciega despierta una reacción 'motiva. En cambio, por ser Celia menos protagonista que Ursula, por no narrarse en orden cronológico los sucesos de su vida y por sentirse mucho más la mano del autor en la presentación de sus personajes, Celia no cobra tanta vida como Ursula y por lo tanto su decadencia física y su muerte no provocan ningún sentimiento en el lector. Además, le muerte de Ursula se reviste de cierto simbolismo cristiano atemperado por una nota medio tragicómica y medio fantástica. Un Domingo de Ramos, Amaranta Ursula y Aurelicno 
imaginan que ya se murió la anciana y la cargan por la nuca y los tobillos, Cuando los niños fingen no oír sus gritos, la misma Ursula cree que ya está muerta: "Entonces Ursula se rindió a la evidencia. 'Dios mío,' exclamó en voz baja. 'De modo que esto es la muerte' ," (p. 290). Cuatro días después, el Jueves Santo, amanece muerta de verdad entre ciento quince y ciento veintidós años de edad.

Las distintas escenas en que interviene Celia en la primera parte de Respirando el verano, quedan aclaradas para el lector gracias al resumen con que empieza la segunda parte. El estilo seudo-enciclopédico de estos renglones se destaca por el contraste con el estilo altamente florido del resto de la novela. La abundancia de los pretéritos, las enumeraciones y las alusiones a acontecimientos todavía no presentados hacen pensar en el primer párrafo del capítulo seis de Cien años de soledad, en el cual se resume la actuación guerrera del coronel Aureliano Buendía: "El coronel Aureliano Buendía promovió treinta y dos levantamientos armados y los perdió todos..." (p. 94).

Celia llegó al pueblo la mañana del veintiséis de diciembre de mil ochocientos setenta y uno... Desmontó y penetró allí y allí se quedó por espacio de setenta y siete años, en el transcurso de los cuales parió once hijos y sufrió siete velorios entre ellos el de su esposo. Nunca más montó a caballo y durante esos setenta y siete años, no salió sino doce veces al pueblo (ella llevaba, al respecto, una cuenta rigurosa) y sus otras salidas, esta vez por los lados de la playa, fueron con sus nietos para tomar los baños de mar. Su ausencia en un hospital de Panamá, cuarenta y sies años después duraría dos meses. (p. 131).

Otro punto de relación entre Celia y el coronel Aureliano es su percepción extrasensorial. Además de los casos ya citados, mientras Celia está en el hospital de Panamá, anuncia la herida de Jorge (confundiendo el nombre con el de otro hijo muerto) con la misma seguridad que caracteriza los intuiciones de Aureliano: " ${ }_{-}$¡Han herido a Carlos, le han dado un balazo en la mano derecha!' (p. 174). Al llegar sola al pueblo de su novio, Celia logra dar con la casa de una manera casi mágica: "y se dirigió sin preguntar como guiada por un olor, a la casa de paja que quedaba bajo los dos almendros en un ángulo de la plaza" (p. 131).

Aunque a Celia no la persigue el miedo de engendrar una criatura con cola de cerdo, el incesto es un tema tan importante en una novela como en la otra. En el caso de las matriarcas, cuando el protomacho José Arcadio recuerda su iniciación sexual con Pilar Ternera, "se encontraba con el rostro de Ursula" (p.31). Este toque junguiano se presenta discretamente en Cien años de soledad y de una manera más arquetípica que freudiana. En cambio, el amor que siente Celia por su hijo Horacio se elabora mucho más y aparece más bien como una anormalidad sicológica individual: "Si no fuera mi hijo habría sido mi amante. Es el único que me regocija y me llena de rubor cuando me habla" (p. 168).

EL DR. MILCIADES DOMINGUEZ AHUMADA -- JOSE ARCADIO BUENDIA, EL CORONEL AURELIANO, PRUDENCIO AGUILAR, MELQUIADES.

A pesar de que el marido de Celia es un personaje secundario que no participa activamente en ninguna escena, también parece haber influido en la gestación de Cien años de soledad. José Arcadio Buendía se casa con su prima Ursula, en tanto que el Dr. Milciades se 
casa con su sobrina. Aunque no tiene la curiosidad intelectual de José Arcadio, el Dr. Milciades es un hombre culto que todas las tardes hojeaba la Iliada o escuchaba recitársela a su hija Julia. Librepensador como José Arcadio, no quiso aceptar los óleos del sacerdote durante los últimos momentos de su agonía.

El noviazgo del Dr. Milciades con su sobrina, a quien conocía desde la niñez, hace pensar en el noviazgo de Aureliano Buendía con la todavía impúber Remedios Moscote. Celia recuerda cómo "muchas veces él la sentaba en sus piernas para que jugara con la gruesa leontina de su reloj"' (p. 133). Desde luego que García Márquez elabora mucho más este episodio inyectando toques cómicos por medio de la exageración e introduciendo una nota arquetípica que refuerza el aspecto universal de la obra. Cuando Aureliano informa a su padre que quiere casarse con Remedios Moscote, la respuesta del fundador de Macondo hace pensar en Romeo y Julieta y en otras tantas parejas cuyos sentimientos amorosos han tenido que enfrentarse al odio entre familias: ' ' 'El amor es una peste,' tronó, 'Habiendo tantas muchachas bonitas y decentes, lo único que se te ocurre es casarte con la hija del enemigo' ", (p. 66). El padre de Remedios no quiere rechazar a Aureliano pero queda asombrado ante la selección de éste: "'Tenemos seis hijas más, todas solteras y en edad de merecer, que estarian encantadas de ser esposas dignísimas de caballeros serios y trabajadores como su hijo, y Aurelito pone sus ojos precisamente en la única que todavía se orina en la cama" ", (p.67). Durante el noviazgo, Aureliano enseña a Remedios a leer, a escribir y a dibujar "en un cuaderno con lápices de colores casitas con vacas en los corrales y soles redondos con rayos amarillos que se ocultaban detrás de las lomas" (p. 71). Poco después de llegar Remedios a la pubertad, se celebra el matrimonio y, como ocurre tantas veces en Cien años de soledad, el aspecto pintoresco de Remedios se complementa con su bondad humana transformándose así una caricatura en un verdadero personaje. Por su espíritu alegre, es la única persona capaz de intervenir en las disputas entre Rebeca y Amaranta. Atiende con mucho cariño a José Arcadio Buendía, envejecido y amarrado al castaño, y acepta en la casa al hijo ilegitimo de Aureliano. Su muerte afecta profundamente a toda la familia.

En una prefiguración de las visitas póstumas de Prudencio Aguilar, el fantasma del Dr. Milcíades sigue apareciendo y acostándose con Celia once años después de su muerte. El mismo fantasma también persigue a Julia agregándose un motivo más al tema incestuoso. En Cien años de soledad, ese tema del fantasma se reviste tanto de humorismo como patetismo. Cuando Ursula se da cuenta que el fantasma de Prudencio Aguilar está lavándose las heridas de la garganta causadas por la lanza de José Arcadio Buendía, ella le coloca tazones de agua por toda la casa. La persistencia del fantasma acaba por obligar a José Arcadio Buendía y a su esposa a abandonar el pueblo y a trasladarse a Macondo. Años después, vuelve a aparecer el fantasma de Prudencio, envejecido y dispuesto a perdonar a su enemigo porque se sentía tan solo en la muerte.

Además de su nombre, el Dr. Milcíades se relaciona con el gitano Melquíades por su dentadura postiza. Celia dice: "me parece escuchar el paladeo de sus encías, igual que cuando se sacaba la caja de dientes y la ponía a humedecer en el vaso de agua" (p. 161). La dentadura postiza de Melquíades adquiere mayor importancia al presentarse como otro de los muchos milagros de los gitanos capaz de rejuvenecer a la gente y aun cobra vida poética propia dentro del vaso: "y el vaso con la dentadura postiza donde habían prendido unas 
plantitas acuáticas de minúsculas flores amarillas", (p. 68).

\section{JORGE--JOSE ARCADIO EL PROTOMACHO Y EL CORONEL AURELIANO}

La primera indicación de un parentesco entre las dos novelas ocurre en el capítulo inicial de Respirando el verano. Se trata de la llegada inesperada del macho gigantesco Jorge, hijo mayor de Celia y del Dr. Milcíades. Jorge igual que José Arcadio rezuma sexo, pero de una manera menos explícita. Llega al pueblo moñtado a caballo, formando los dos un bloque agigantado por la perspectiva de Anselmo, su sobrino de nueve años de edad, que jugaba en ese momento con un corcelito de palo. Después de alzar a Anselmo; Jorge abraza a Celia: "El gigante la atrajo con frenesí, le besó los cabellos y la frente, reteniéndola entre sus brazos. La viejecita parecía una niña desamparada, alegre y desamparada, entre los garfios musculares del hijo" (p. 14). José Arcadio también "fue directamente a la cocina" donde "Ursula saltó a su cuello gritando y llorando de alegría" (p. 83). Después, Jorge alza a Fela la ciega, quien, como Rebeca Buendía, vive con la familia sin ser pariente: "Y rodeó livianamente la cintura de la ciega con temor de quebrar aquella vítrea delgadez con su entusiasmo de toro"' (p. 15). En los ojos de Anselmo, Jorge es "una montaña viva"' (p. 13). El capitulo se cierra mostrando a Jorge acostado en un taburete de cuero que parecía minúsculo. Los puntos de contacto con el protomacho macondino se intensifican al enterarse el lector en un capítulo posterior que cuando Jorge volvía al pueblo de sus viajes periódicos, jugaba dominó y visitaba "a las ocho mozas" (p. 112). Por cierto que las visitas de José Arcadio a la tienda de Catarino son mucho más inolvidables, como cuando exhibe su miembro tatuado y se rifa a las prostitutas. José Arcadio también aventaja a Jorge como personaje por representar al terrateniente insaciable que acapara las tierras con trámites seudo-legales.

El deseo de José Arcadio de casarse con su "casi hermana" Rebeca tiene vagos antecedentes en las relaciones entre Jorge y su hermana Berta. Esta rememora con insinuaciones incestuosas cómo su hermano mayor la cuidaba:

Berta sentía la mano del hermano penetrándola, empequeñeciéndola hasta la infancia... Y los ojos de él, severos, recriminándola, mientras decía: "Ahora sí estamos fregados, he quedado de niffera" y luego, sin transición, liberando un cálido deseo, una comprensión que envolvía las caricias para una hija futura, la subía a las piernas, pasando la gran mano por los rizos dorados, por las húmedas mejillas, por los párpados enjoyados con lágrimas de duda, de estupor y de final entusiamo. (p. 111).

Sin embargo, el aspecto gigantesco de Jorge no logra mantenerse a través de toda la novela. Despues de dominar todo el primer capitulo, no se le vuelve a mencionar hasta el capítulo décimo. Luego resulta herido al intervenir en las disputas matrimoniales entre Berta y su esposo borracho Andrés. Se refuerza la insinuación incestuosa cuando Berta indica que lo va a curar a pesar de la envidia de su prima Sara:

...Vio su traje negro cubierto por una gasa de leve mugre y debajo de él-flácido, agitado por la envidia-su pecho ronco tostándose en el purgatorio de un duro pensamiento. Sara indagó con voz turbia: 
$-¿$ Lo vas a curar?

No respondió. Cogió con su mano izquierda el brazo derecho de Jorge, lo sostuvo firmemente y subió con él los escalones del pretil. Todos la vieron-maciza en la puerta, con el rostro enmarcado en el oro de su cabellera trenzada-sosteniendo la mano de Jorge como un trofeo, como un rojizo cáliz en que, convergían el calor, la vibración y la ignominia de aquel rudo verano. Cuando cerró la puerta dos lanzas de luz acribillaron la madera y se quedaron alli, cruzadas y temblando, sobre el corredor abrasado. (p. 127)

Aunque la participación de Jorge en la Guerra de los Mil Días ocurre cronológicamente antes de le escena susodicha y precediendo su paraición inicial en la novela, los comentarios al respecto no se hacen hasta la segunda parte de la obra dando la impresión de que va perdiendo su fuerza descomunal. Su regreso de la guerra hecho un desastre y su desilusión anterior presagian la situación similar del coronel Aureliano. A los diez y nueve años, Jorge entró en la guerra lleno de entusiasmo y no tardó en ganar las estrellas de capitán. Sin embargo, al dar muerte a bayonetazos a un enemigo, sufrió un choque que le iba a durar toda la vida: "Al principio fue la guerra, esa alegre aventura en la que entraba todo menos la muerte. Pero ahora llevaba a aquel hombre dentro de él. Por siempre, por siempre, aquellos ojos circulando como peces entre las órbitas sangrientas, lo perseguirían en silencio" (p. 120). Después, a la edad de treinta y ocho años, caminando al encuentro de Andrés, Jorge se siente enajenado del Jorge severo y valiente que todos admiran: "El, en cambio, sabía que había vivido al margen de sí mismo"' (p. 118).

Mientras que la actitud de Jorge frente a la guerra es totalmente personal, la desilusión del coronel Aureliano adquiere una dimensión histórica que constituye un ejemplo más de la mayor trascendencia de Cien años de soledad. Además de darse cuenta de que está peleando sólo "por orgullo" ( p. 121), el coronel Aureliano se desilusiona de sus correligionarios liberales en Bogotá : "Estaremos perdiendo el tiempo mientras los cabrones del partido estén mendigando un asiento en el congreso" (p. 120). Cuando los "seis abogados de levita y chistera"'(p.147) le piden que renuncie a todo el programa liberal: "la revisiónkle los títulos de propiedad de la tierra...la lucha contra la influencia clerical... las aspiraciones de igualdad de derechos entre los hijos naturales y los legitimos" (p. 147), el coronel Aureliano ya no aguanta más. Con su acostumbrado laconismo, suelta a su compañero Gérineldo Márquez: “Terminó la farsa, compadre, ... Vámonos de aqui, antes de que acaben de fusilarte los mosquitos" (p. 149). El entusiasmo con que el coronel Aureliano se lanza a la última guerra de fines del siglo también refleja la actitud de García Márquez frente al acuerdo de 1958 entre liberales y conseryadores de alternar en la presidencia por dieciséis años:

Nunca fue mejor guerrero que entonces. La certidumbre de que por fin peleaba por su propia liberación, y no por ideales abstractos, por consignas que los políticos podian: oltear al derecho y al revés según las circunstancias, le infundió un entusiasmo enardecido. (p. 149)

\section{JULIA, SARA, ANA--AMARANTA}

La actitud ambigua hacia el sexo que muestra Amaranta Buendía se anticipa en tres personajes femeninos de Respirando el verano. Julia, hija mayor de Celia y del Dr. Milciades, ama tanto a su padre que de adolescente revela "una terca disposición a no amar 
ni entender a otro hombre" (. 38). Cuando su primo Simón la pretendia, "ella miró su bigote flotante como si mirara un gusano" (p. 38). El primo se venga volviendo después de su muerte en la forma de un fantasma desnudo. A los dieciséis años, Julia fue llevada a un convento de Cartagena donde sólo permaneció dos años. A la edad de treinta, por primera vez sintió "unos alfiletazos de placer" (p. 54) al conocer al capitán José Manuel Espinar, a quien le tocó trasladar al Dr. Milcíades preso desde la cárcel municipal al lanchón del gobierno. Después de esa visita, el capitán Espinar volvió tres vecess más en vano intento de despertarle el amor a Julia. Hacia el fin de la novela, Celia recuerda cómo Julia se mostró indiferente aun en el momento de peligrar la vida del Capitán: " $L a$ noche en que casi matan a Espinar--la noche en que tuvimos que ocultarlo en mi propio cuarto mientras los macheteros, incrédulos e iracundos, se sentaron en el pretil esperando que saliera para poder descuartizarlo-- Julia se acostó sin despedirse de nosotros. Parecía fatigada de prolongar una comedia" (p. 177). De una manera semejante; Amaranta parece hacer un esfuerzo por enamorarse del coronel Gerineldo Márquez pero cuando él le propone matrimonio, ella lo rechaza categóricamente: "--No me casaré con nadie -- le dijo--, pero menos contigo. Quieres tanto a Aureliano que te vas a casar conmigo porque no puedes casarte con él" (p. 123). Después de renovarse el noviazgo y prolongarse durante los años de las guerras civiles, Amaranta vuelve a rechazarlo: "Olvidémonos para siempre--le dijo--, ya somos demasiado viejos para estas cosas"' (p. 144).

Julia, a la edad de cuarenta y cuatro años, conoció al mercader libanés Salomón Niseli. Se fue con él pero regresó treinta y ocho meses después y se instaló en la casa "como si nada hubiese ocurrido, como si únicamente hubiese estado de visita donde Leonor o donde cualquiera otra de las primas, sacó su taburete y se sentó, sofocada y adusta, a ventearse furiosamente con su abanico de paja" (p. 49). ${ }^{7}$ A los tres meses, llega el libanés y se instala (n la casa, como lo habria de hacer Melquiades, por veintidós años... en su propio cuarto (p. (68).

Tanto en sus relaciones con el libanés como en el breve noviazgo con el capitán Espinar, Julia representa la imagen de la Madre Terrible junguiana. Respecto al libanés:

...ella --monumental y sórdida, estrictamente vegetal, poseida, sin embargo, de su fugaz importancia--ponía en movimiento sus grandes círculos sebáceos, tintineantes, $y$, desnuda, en pie, con sus brillantes rodillas de oro encendidas entre las moscas, lo introducía a aquel pantano uteral y fofo donde chapoteaba su deseo y terminaba por caer, rendido, aspirando las miasmas de un estentor ronco, grasoso, de múltiples visceras en erección, ampliadas por el tedio de vibrantes insectos.(45)

El capitán Espinar había logrado inicialmente romper la indiferencia de Julia con "el lento arrastre de sus palabras y esa música forastera-- ¿de montaña o de llano?" " (p. 56) y ella "pareció sacar todos sus tentáculos (sus ojos, su memoria, su apetito) y succionar, hambrienta y desdichada, entre aquella vegetación, ebria de juventud, entre la cual, vibrando como una hilera de pájaros en la linde de un bosque, flotaban los dientes bajo las cañas de sus bigotes dorados" (p. 56). Igualmente junguiana es la "pasión pantanosa"' (p. 236) que

\footnotetext{
${ }^{7}$ Ursula se comporta de la misma manera al regresar con la muchedumbre después de una ausencia de cinco meses: "Le dio un beso convencional (a su marido), como si no hubiera estado ausente más de una hora...' (p. 38).
} 
siente Amaranta por su sobrino Aureliano José. Hasta hay una leve insinuación de amor incestuoso entre Amaranta y su propio hermano Aureliano. Al describir cómo Amaranta arregla el cadáver del coronel Aureliano, el narrador se siente obligado a negar la posibilidad del amor, lo que produce exactamente el efecto contrario, o sea que siembra la duda en la mente del lector: "Ella ayudó a levantar el cuerpo. Lo vistió con sus arreos de guerrero, lo afeitó, lo peinó, y le engomó el bigote mejor que él mismo no lo hacía en sus años de gloria. Nadie pensó que hubiera amor en aquel acto, porque estaban acostumbrados a la familiaridad de Amaranta con los ritos de la muerte' '(p. 236).

Además de Julia, dos personajes secundarios, Ana y Sara, parecen haber contribuido a la caracterización de Amaranta. Cuando Horacio, hermano menor de Jorge, le propone a su novia Ana que se casen en enero, ella contesta: "--Sí, será un enero. Cuando los almendros estén florecidos y ninguno de los dos esté sobre la tierra'” (p. 157). García Márquez utiliza el mismo tipo de respuesta para Amaranta cuando Crespi le propone matrimonio, sólo que la respuesta de Amaranta es más vaga: " "-Por supuesto, Crespi--dijo--, pero cuando uno se conozca mejor. Nunca es bueno precipitar las cosas"' (p. 87). Al prolongarse el noviazgo, Crespi trata de fijar la boda para una fecha próxima. El rechazo inesperadamente cruel de Amaranta lo lleva al suicidio: "--No seas ingenuo, Crespi--sonrió-- ni muerta me casaré contigo', (p. 98).

Sara, prima de Julia, anda vestida de luto con "sus ojos amargos, concentrados, ebrios de ansiedad y remota lujuria. Parecía embebida en un placer infernal y callado. Algo de lo que nada ni nadie que no fuese su propia y enigmática voluntad podría participar"' (p. 19). En tanto que nunca se le revela al lector por qué Sara anda vestida de luto, la decisión de Amaranta no sólo queda explícita sino que se presenta de un modo muy dramático: "puso la mano en las brasas del fogón"' y la amarró con una "venda de gasa negra...que había de llevar hasta la muerte"' (p. 100) como testimonio público de su remordimiento por el suicidio de Pietro Crespi. Sin embargo, tanto en la caracterización de Amaranta como en la del coronel Aureliano y la de los demás personajes, García Márquez se siente más fascinado por los aspectos pintorescos, dramáticos y arquetípicos de sus personajes que por su verosimilitud y su complejidad sicológica. Además de lo susodicho, se recuerda a Amaranta como la mujer que acariciaba sexualmente a su propio sobrino Aureliano José, lo que había de repetir dos generaciones después con el futuro "papa" José Arcadio. No obstante, " Amaranta parecía llevar en la frente la cruz de ceniza de la virginidad"' (p. 222) y hasta después de acostarse para morir, "obligó a Ursula a dar testimonio público de su virginidad" (p. 240), en una alusión a la costumbre practicada por algunos pueblos en la noche de bodas. ${ }^{8}$ Las instrucciones para tejer la mortaja las recibe Amaranta de la Muerte, personificada en "una mujer vestida de azul con el cabello largo de aspecto un poco anticuado, y con un cierto parecido a Pilar Ternera en la época en que las ayudaba en los oficios decocina", (p. 238). Es tan humana la Muerte que hasta llegó a pedirle a Amaranta en una ocasión "el favor de que le ensartara una aguja" (p. 238). En Respirando el verano, Rojas Herazo también había personificado a la Muerte, pero en la forma de un "hombrecillo recostado al almendro, mirándolo (al moribundo Horacio) con sus ojos de piedralipe bajo el enorme sombrero' ' (p. 159). El hombrecillo desaparece luego sin actuar más en la novela.

\footnotetext{
${ }^{8}$ Véase Ousmane Socé, Karim, roman sénégatais (1935), Paris: Nouvelles Editions Latines, 1948, p. 147.
} 


\section{SALOMON NISELI--MELQUIADES}

Aunque el nombre del gitano Melquíades en Cien años de soledad parece provenir del Dr. Milcíades, el personaje de Respirando el verano que más le corresponde a aquél es el llamado libanés, cuyo verdadero nombre, Salomón Niseli, no se revela hasta el último capitulo. Las frases iniciales de ese capitulo, como otras frases ya citadas, tienen un marcado sabor a Cien años de soledad: "Salomón Niseli tiene sesenta y dos años, nueve meses y seis días, los ojos color humo, el bigote caído y un antiguo dolor de hígado reflejándose sobre el vientre en esta tarde de verano. Viene caminando, bajo la hilera de almendros amarillos desde el otro lado del mundo" (p. 197). El libanés es el único extranjero en toda la novela y su trabajo de vender baratijas sugiere un parentesco tanto con Melquiades como con los primeros árabes que llegaron a Macondo con " pantuflas y argollas en las orejas, cambiando collares de vidrio por guacamayas' (p. 39). Por cierto que Melquáades cobra una mayor importancia al asociarse con la serie de inventos, por su amistad con el fundador José Arcadio Buendia, por sus dos muertes, y por ser de cierta manera el narrador. Cuando el penúltimo Aureliano acaba por descifrar el manuscrito en sánscrito de Melquíades, se da cuenta que "Era la historia de la familia, escrita por Melquíades hasta en sus detalles más triviales, con cien años de anticipación"' (p. 349). Ese truco literario del descubrimiento de un manuscrito proviene tanto del Quijote como de La vorágine, pero lo original de Cien años de soledad es que el truco no se revela hasta las últimas páginas de la novela.

Aunque no cabe la menor duda que la caracterización y ciertos toques estilísticos de Respirando el verano han influido en la gestación de Cien años de soledad, una comparación global de las dos obras reafirma la mayor complejidad y la enorme riqueza de la obra de Garcia Márquez. Mientras que Cien años de soledad es la crónica del pueblo de Macondo tanto como la de los Buendía, Respirando el verano presenta a la familia de Celia casi en un vacío social. El nombre del pueblo nunca se revela pero se puede descubrir su ubicación geográfica por la mención de las ciudades de Cartagena, Barranquilla, Ovejas y Sincelejo, y por su situación a orillas del mar. Así es que el escenario debe ser un pueblo del Golfo de Morrosquillo, al sur de Cartagena, al oeste del río Magdalena; Macondo, como se sabe, suele identificarse con el pueblo de Aracataca al sur de Santa Marta y al este del río Magdalena.

La identificación geográfica del pueblo, sin embargo, es lo de menos. Si se compara Respirando el verano con la segunda novela del propio Rojas Herazo, En noviembre llega el arzobispo (1967), se ve que Rojas persigue distintos fines en las dos obras. En ésta un pueblo parecido se presenta con muchas familias que compiten por la atención del lector dando la impresión de una verdadera sociedad. En cambio, Respirando el verano se concentra casi exclusivamente en una sola familia. En cuanto a la vida económica del pueblo, sólo se sabe que existe un matadero cerca de la playa y que algunos de los habitantes viven de la pesca. Parece que el mismo autor se dio cuenta del vació en que había puesto a la familia y al final de la novela introdujo de una manera algo forzada otros habitantes del pueblo. En el capítulo antepenúltimo, Horacio, moribundo, recibe la visita del doctor Stanford, "negro, orondo y grasoso como un cacique del Senegal"' (p. 184). Poco después llega el cura, "mulato de ojos saltones y cachetes de gelatina" (p. 189), pero ni el uno ni el otro actúan tan pintorescamente como sus colegas profesionales de Macondo: el médico anarquista Alirio Noguera o el Padre Nicanor, el de la levitación. El afán de agregar a Respirando el verano 
una dimensión más panorámica se nota aún más en elúltimocapitulo. La caminata del libanés por el pueblo es utilizada por el autor para presentar personajes que ni se habían mencionado antes. Don Rómulo Vásquez A tehortúa se identifica como el amo del pueblo. Es un "ventrudo mulato de grandes mostachos de azafrán...partiendo la brisa del mar con su vientre repleto de quimicas agrarias"' (p. 198). Liborio González, otro rico, con sus "depósitos cargados de arroz" responde al saludo del libanés "desde su larga osamenta frunciendo las lívidas narices' ' (p. 197). Doña Clarisa de Romero, diabética con espejuelos y los "pies heridos por su propia sangre, cuando se llena de rubias hormiguitas a las dos de la tarde" (p. 198), tiene una hija loca "a quien se le aparece Dios--desnudo, haciéndole señas con los hombros hundidos en la alberca" (p. 198). La hija también busca "la espada de San Gabriel perdida entre los palotes y las ollas de la cocina"' (p. 199). Como puede apreciarse, todos son personajes pintorescos que podrían haber enriquecido la novela si el autor hubiera decidido de antemano entremezclarlos con los miembros de la familia.

En cambio, García Márquez, al trazar la historia de una sola familia, la relaciona intimamente con la sociedad. En efecto, uno de los grandes logros de la novela es la transformación de Macondo en un microcosmo tanto de Colombia como de todo el inundo occidental. Mientras los antecedentes de la familia de los Buendía remontan al asalto del pirata Francis Drake, y el descubrimiento del enorme galeón español evoca el período de la Conquista del siglo XVI, el éxodo de Riohacha en busca de "la tierra que nadie les habia prometido" (p. 27) es una alusión directa a la historia del éxodo de los hebreos de Egipto bajo Moisés. Es más, García Márquez obliga al lector a retroceder históricamente hasta los tiempos míticos, cuando la fundación de un Macondo utópico sugiere una arcadia semejante a la edad de oro del Quijote donde no existían las palabras "mio" y "tuvo" : "José Arcadio Buendía, que era el hombre más emprendedor que se vería jamás en la aldea, había dispuesto de tal modo la posición de las casas, que desde todas podía llegarse al río y abastecerse de agua con igual esfuerzo, y trazó las calles con tan buen sentido que ninguna casa recibía más sol que otra a la hora del calor', (p. 15). El marco de la novela entera lo podrían constituir el génesis y el holocausto apocalíptico, o sea la creación de un río con "piedras pulidas, blancas y enormes como huevos prehistóricos" (p. 9) y el "pavoroso remolino de polvo y escombros centrifugado por la cólera del huracán bíblico", (p. 350).

Mientras que las guerras civiles del coronel Aureliano y la actuación de la empresa bananera reflejan directamente la historia de Colombia, Garcia Marquéz extiende con la mayor naturalidad los límites tanto geográficos como históricos de la novela más allá de su propio país. Algunos de los personajes viajan a distintas partes de los Estados Unidos, de Europa y de $\Lambda$ sia; el protomacho José Arcadio " "le había dado sesenta y cinco veces la vuelta al mundo"' (p. 84). y se descubre que también hay un Macondo en Tanganyika, Africa cuando allá llega el avión pedido por Gastón. El apellido de Mauricio Babilonia, las tarjetas postales de Pietro Crespi con las "ciudades antiguas de cuya pasada grandeza sólo quedaban los gatos entre los escombros" (p. 97); "el cinturón de castidad" de Ursula, la alquimia, los inventos y el descubrimiento de que el mundo es redondo, el victorianismo de la casa nueva de los Buendía y el despilfarro de dinero por Aureliano Segundo son algunas de las alusiones a distintas épocas históricas sin que se precisen las fechas. La única época histórica que parece faltar de este gran mural panorámico es el siglo de las luces cuyo culto de la razón tal vez hubiera desentonado con el :nundo mágicorrealista concebido por Garcia Márquez en la época antirracionalista de 1967. 
Además de esbozar un compendio de la historia universal, Cien años de soledad también intenta captar en forma abreviada la totalidad de la literatura occidental desde Homero hasta los mismos contemporáneos de García Márquez. Siguiendo cronológicamente las alusiones a la Biblia y a la épica griega, los cuatro amigos del librero catalán estudian a Séneca y a Ovidio; Gabriel se lleva a París las obras completas de Rabelais; el nombre de Catarino, el cantinero homosexual, proviene de Catalinón de El burlador de Sevilla; Francisco el Hombre hace pensar en Cantaclaro de Rómulo Gallegos; Victor Hugues, Artemio Cruz y Recamadour son alusiones directas a novelas contemporáneas de Alejo Carpentier, Carlos Fuéntes y Julio Cortázar respectivamente.

En su afán totalizador, García Márquez llega a servirse hasta de los cuatro elementos naturales ${ }^{9}$ para integrar una de las estructuras novelísticas. Los variantes del agua, del fucgo, de la tierra y del aire constituyen cuatro motivos recurrentes distintos. El agua está presente en el río de Macondo y el hielo de Melquíades; en los baños de Aureliano José, de Remedios la Bella y del "papa" José Arcadio; en los viajes marítimos y fluviales de Sir Francis Drake, del protomacho José Arcadio y de José Arcadio Segundo con las matronas de Francia; en la lluvia de "cuatro años, once meses y dos dias" (p. 267). El fuego desempeña un papel esencialmente negativo. Además de los fusilamientos y de la masacre de los peones bananeros, hay otros episodios en que aparece: la bisabuela de Ursula se asustó tanto con el ataque de Sir Francis Drake que "se sentó en un fogón encendido" (p. 24); la mulata adolescente se acuesta con más de sesenta y tres hombres cada noche para pagarle a su abuela "el valor de la casa incendiada"' (p. 52) por su descuido; Amaranta mete la mano en el fuego arrepentida por el suicidio de Pietro Crespi; Fernanda "se quemó los dedos tratando de prender un fogón por primera vez en la vida" (p. 305) después de la fuga de Santa Sofía de la Piedad. La tierra la come Rebeca quien después se casa con el protomacho José Arcadio, el que acapara la tierra durante las guerras civiles; el coronel Aureliano se desilusiona de las guerras cuando se da cuenta de la complicidad entre los terratenientes liberales y conservadores; y por supuesto, la tierra es fundamental para la explotación bananera, que altera la historia de Macondo. Por el aire, flotan la estera voladora, Remedios la bella con las sábanas de Fernando, las "minúsculas flores amarillas" que indican la muerte del fundador José Arcadio Buendía, y las mariposas de Mauricio Babilonia. Al fin de la novela, el viento tibio de Macondo se vuelve "un pavoroso remølino de polvo," un "huracán bíblico" (p. 350) que acaba con e' pueblo. Una clave que reafirma no sólo la existencia de los cuatro elementos naturales como elementos estructurantes sino también el aspecto totalizador de toda la novela es la "casualidad" de que sean cuatro los adolescentes que matan al "papa" José Arcadio y cuatro los amigos del librero catalán.

9 " "Centuries ago it was believed that the four possible combinations of the four "principles", hot, cold, moist and dry, produced, in the organic world, the four humors, and, in the inorganic world, the four elements. The hot and dry combination produced choler and fire, the hot and moist blood and air, the cold and moist phlegm and water, the cold and dry melancholy and earth. The four elements are not a conception of much use to modern chemistry--that is, they are not the elements of nature. But, as Bachelard's book and its companion works show, and as an abundnace of literature down to Eliot's girtets also shows, earth, air, water and fire are still the four elements of imaginative experience, and always will be," Northrop Frye, Preface to Gaston Bachelard, The Psychoanalysis of Fire, (1938), trans. C.M. Ross, Boston: Beacon Press, 1964, p. VII. 
A pesar de que Cien años de soledad es un compendio de la historia y de la cultura del mundo desde "aquel paraiso de humedad y silencio, anterior al pecado original" (p. 17) hasta el futuro holocausto atómico, la cronología es lineal y no le causa ningún problema al lector. En cambio, Respirando el verano, que sólo abarca tres generaciones de la misma familia, sufre de la alternación continua y confusa de distintos planos cronológicos, al estilo de William Faulkner. Asi como el lector de Cien años de soledad necesita un esquema genealógico,el de Respirando el verano necesita un esquema cronológico. Apuntando todas las fechas de la novela y haciendo calistenias matemáticas se llega a descifrar la cronología con una exactitud que rechazó García Márquez en la composición de Cien años de soledad porque no correspondía con su vision mágicorrealista del mundo. Celia nació en 1855 , se casó en 1871 y en el transcurso del mismo año nació Julia, la hija mayor. A los diez años de casados, en 1881, Celia y Milcíades ya tenían siete hijos: Jorge estuvo en el ejército en 1901, el mismo año en que Julia conoció al capitán Espinar; a Celia se le murió el esposo en 1911; en 1917 Celia sufrió su última caída y estuvo en el hospital de Panamá, Julia conoció al libanés, Berta se casó con Andrés y un año después éste por poco mata tanto a Berta como a Jorge; Horacio, nacido en 1894, muere en 1921; el "presente" de la novela es 1931 cuando Celia se rejuvenece en el mar; pero la acción continúa y como el libanés ya cumplió veintidós años de estar instalado en la casa, el autor nos sitúa en 1940. En otro capitulo, Julia cumple setenta y dos años, avanzando la fecha a 1943; y como Celia muere setenta y siete años después de casarse, la acción no se cierra hasta 1948. Todas eitas fechas en sí no tienen importancia pero sin ellas, sería casi imposible reconocer a los personajes, a quienes el autor, como Faulkner, alude con pronombres antes de establecer su identidad. La cronologia también ayuda para aclarar el parentesco entre un número demasiado grande de protagonistas. Lo que en Faulkner constituye una técnica que sirve para crear un ambiente acrónico, para identificar entre sí a personajes de distintas generaciones, y para obligar al lector a participar más activamente en la novela, se reduce en Respirando el verano a un puro alarde tecnicista de recorrer toda la cronología desde 1855 hasta 1948 mientras la duración del tiempo novelístico parece corresponder a la duración del verano de 1931.

Más logrado resulta el estilo de Respirando el verano, tanto por la anticipación de recursos empleados en Cien años de soledad como por sus propias cualidades poéticas. Además de las semejanzas ya señaladas, hay que recalcar la importancia de las alusiones al futuro por medio del condicional, que adapta García Márquez con su acostumbrada destreza. En Cien años de soledad, la primera oración del capítulo primero se ve reproducida en forma modificada en la primera oración del cápitulo diez; abarcando entre las dos casi todas las generaciones de la novela desde el fundador José Ar adio Buendia hasta el "papa' José Arcadio:

Muchos años después, frente al pelotón de fusilamiento, el coronel Aureliano Buendia había de recordar aquella tarde remota en que su padre lo llevó a conocer el hielo. (p. 9)

Años después, en su lecho de agonía, Aureliano Segundo había de recordar la lluviosa tarde de junio en que entró en el dormitorio a conocer a su primer hijo. (p. 159).

La frase repetida: "había de recordar," que establece de un modo tan singular la cosmovisión de toda la obra bien puede haberse inspirado en el uso del condicional con el 
mismo intento por Rojas Herazo en la oración siguiente y otras semejantes. Nótense, sin embargo las diferencias. Mientras el relativo laconismo de García Márquez contribuye a crear en el lector un efecto deslumbrador, la mayor extensión de la oración de Rojas, su mayor adjetivación, los efectos onomatopéyicos y las imágenes se combinan para producir una prosa más rica en sí pero que no graba tanto en la mente del lector el futuro derrumbe de la casa.

Queria huir, irse lo más lejos de aquellas frases en jirones, de los ojos iracundos de los hermanos como perros acezando en las tinieblas, de la casa que un día terminaría por caer con funeral estruendo para sepultarlos a todos entre su madera y su polvo y sus incontables sollozos apretados y resecos en el barro de sus paredes. (p. 96)

En efecto, a pesar de ciertas semejanzas, el estilo de Rojas Herazo es muy distinto de aquél de García Márquez. Por la abundancia de imágenes surrealistas, recuerda el estilo de García Lorca, pero por la extensión y la sonoridad de las oraciones, hace pensar en la prosa brillante de un modernista como Enrique Larreta:

Alzó la vista y vio la plaza hirviendo, temblorosa, contra una vasta lámina de vidrio con sus casas de paja y sus árboles de almendro retorciéndose como si los viera reflejados en el agua. (p. 11)

Veía la plaza, abierta y dorada, con sus delgados senderitos grabados en la yerba. Las techumbres flotaban como estrellas de miel entre el rumor de las acacias y los clemones y el delirio de los gallos invisibles. (p. 32)

Lo veía entre la hamaca como un navegnate perdido; sentía la espuma del tiempo (tal vez la espuma de la muerte) susurrando en copos invisibles en torno de aquel navío de tela y escuchaba los pájaros que picoteaban, sangrándola, el interior de aquella frente para volar con sus despojos más lejos todavía, donde el navegante, indefenso, no podría rescatar aquellas porciones que, para siempre, le habían sido arrancadas de su alma. (38)

Aunque estos trozos y otros muchos son verdaderas creaciones estéticas, abundan tanto que a veces llegan a empalagar. También se le puede criticar al autor por el uso excesivo del verbo "flotar" en sentido metafórico-.." una calma recia y majestuosa flotaba en sus facciones como un estandarte"' (p. 180)-- para recalcar aún más la sequía del verano. Del mismo modo hace demasiado hincapié en el verbo "respirar" para subrayar el título de la novela.

Por estos pequeños defectos estilisticos, por la confusión cronológica, por la ausencia de la sociedad pueblerina y por la falta de trascendencia, Respirando el verano no es una novela de primera categoría. No obstante, merece ser rescatada del olvido por haber contribuido poco más poco menos, a la creación de ciertos protagonistas claves de Macondo; por haber sugerido algunos trucos estilísticos; y por haber dado el ejemplo de una interpretación mágica de la costa tropical de Colombia. 
